\title{
A brief overview Component 1 on national REDD+ policies and processes
}

Maria Brockhaus and Monica Di Gregorio

\section{About the GCS-REDD project}

The Global Comparative Study on Reducing Emissions from Deforestation and Forest Degradation (GCS-REDD) is a 4-year global comparative research project undertaken by the Center for International Forestry Research (CIFOR). The project began in 2009 with a study of first-generation REDD+ demonstration and readiness activities. The project consists of four components, focusing on: national initiatives around policy processes and strategies, REDD+ project sites, monitoring and reference levels, and knowledge sharing. The overall goal of the project is to provide REDD+ policymakers and practitioners with the information, analysis and tools they need for effective policy and management decisions. The aim is to ensure effective and cost-efficient reduction of carbon emissions while assuring equitable impacts and co-benefits such as poverty alleviation and biodiversity conservation.

\section{About Component 1}

Component 1 of this study analyses the policy processes which lead to the formulation and implementation of national REDD+ strategies. The study is currently underway in 9 countries (Bolivia, Brazil, Cameroon, the Democratic Republic of the Congo, Indonesia, Nepal, Peru, Tanzania and Vietnam), and partial analysis is being undertaken in 3 additional countries (Burkina Faso, Mozambique and Papua New Guinea).

The research investigates how the formulation and implementation of national REDD+ strategies and their effectiveness, efficiency and equity (3Es) outcomes, depend on existing governance conditions, including the actors involved in the policy process, the mechanisms and structures. More broadly, it analyses how the institutional context, the discursive practices and macroeconomic conditions of the countries affect national policies. The degree of political commitment, the internal power dynamics and the existence of mechanisms for policy learning are analysed to explain the degree of success of policy design and implementation. In addition, the study investigates how the lack of appropriate institutional mechanisms limits the effective targeting of financial incentives to reduce deforestation and achieve broader co-benefits. The study is based on the assumption that the 3 E content of a country's national REDD+ strategy can be enhanced by: (1) understanding the relationship between actors, structure, process, country context and REDD+ policy content; and (2) incorporating this understanding into the design of national policy strategy options for REDD+.

The research objective is to inform national policymakers about how the constraints outlined above can be addressed through adequate policy design in order to achieved improved outcomes. Particular focus lies in providing research-based options for achieving efficient, effective and equitable REDD+ policy strategies. Policy recommendations will include aspects of institutional design for specific country contexts.

Comparative analysis complements in-depth single case study research and assesses the social, political-economic and institutional factors that explain varying $3 E$ outcomes of the REDD+ national strategies. 
In analysing national REDD+ strategies, CIFOR researchers have developed five work modules: a country profile, a media analysis, a policy network analysis, a REDD+ policy content analysis, and a fifth flexible module for specific policy studies that respond to single country research needs (see Table 1 and Figure 1).



\section{Figure 1. The research design}

$3 \mathrm{E}=$ effectiveness, efficiency and equity

REDD+ = reducing emissions from deforestation and forest degradation, and enhancing forest carbon stocks in developing countries 
Table 1. Methods for analysing national REDD+ strategies

\begin{tabular}{|c|c|}
\hline Method & Objective and description \\
\hline $\begin{array}{l}\text { Country profile } \\
\text { a. Detailed guidelines for each } \\
\text { section/subsection }\end{array}$ & $\begin{array}{l}\text { Provides an in-depth description of the national context relevant to REDD+, } \\
\text { the options for REDD+ under discussion and an overview of the policy } \\
\text { dynamics, outlining the key issues and challenges in the country }\end{array}$ \\
\hline b. Open interviews & $\begin{array}{l}\text { Describes drivers of deforestation, general and forest sector governance, } \\
\text { natural resource and carbon tenure, relevant sector policies and programmes, } \\
\text { and design options for REDD+ in terms of monitoring, reporting and } \\
\text { verification; financing; benefit and cost sharing; alignment of institutions and } \\
\text { policies; coordination; identification of key actors; consultation; and policy } \\
\text { events. The profile includes a summary assessment of the } 3 \mathrm{E} \text { implications }\end{array}$ \\
\hline Media discourse analysis & Analyses predominant discourse in the media to examine: \\
\hline $\begin{array}{l}\text { a. Media coding (three major } \\
\text { national daily newspapers) with }\end{array}$ & $\begin{array}{l}\text { - Frequencies, frames (meta topics, topics) and actors (advocates and } \\
\text { adversaries of frames), and their stances (position statements) on: }\end{array}$ \\
\hline $\begin{array}{l}\text { predefined code book, articles } \\
\text { selected based on predefined }\end{array}$ & $\begin{array}{l}\text { - existing REDD+ discourse and the way in which it is shaping the } \\
\text { options negotiated in the national REDD+ arena }\end{array}$ \\
\hline \multirow{3}{*}{ b. Media informant interviews } & - reforms under discussion, both specific to REDD+ and of broader \\
\hline & relevance \\
\hline & $\begin{array}{l}\text { - } \quad \text { actors influencing or using specific discourse } \\
\text { - } \quad 3 E+\text { implications of the various discourses }\end{array}$ \\
\hline
\end{tabular}

Policy network analysis

a. Expert panel

b. In-depth interviews with actors

c. Social organisational survey
Assesses the actors and structural aspects of the REDD+ arena and considers implications for the 3E+ content of REDD+ strategies

Examines questions including:

- Who is involved in national REDD+ policymaking?

- What are their perceptions, interests and power relations?

- What are their networks of information and influence?

Repeated annually, this method can assess dynamics and power relations over time. Results of policy outcomes emerging from components 2 and 3 of CIFOR's GCS research will allow us to assess the efficiency outcomes

REDD+ policy content analysis Identifies existing national strategy documents and provides a detailed content analysis of proposed policies and measures to secure 3 E outcomes and co-benefits

Policy studies

Conducted continuously, as appropriate

Covers specific policies, political economy questions, or options, such as biofuel or soya policies. Reviews specific lessons from reforms, or mechanisms such as existing environmental trust funds. Provides insight into political economy aspects of REDD+ and the implications for effective, efficient and equitable REDD+ design. Flexible application of this module allows for rapid response to emerging research questions

National REDD+ strategy assessment Brings together all 5 previous modules to assess the complete national REDD+ strategy to: (1) identify obstacles and opportunities to realise REDD+ and secure $3 \mathrm{E}$ outcomes and co-benefits, and (2) provide policy recommendations for improved domestic policy design and implementation

The strategy assessment is based on a broad policy context and content analysis of existing REDD+ national strategies (actors, mechanisms, structures)

Global comparative analysis

a. Qualitative comparisons of country case research modules

b. Comparative network analysis

c. Qualitative comparative analysis
Provides guidance for second-generation REDD+ design to address problems appearing in national policy arenas from first generation initiatives. Various factors and country context variables. Draws on data derived from all methods above and provides comparison across national case studies within each method, such as a global comparative media analysis, and across methods analytical lenses will be applied, for example the 3E+ criteria, governance 


\section{Acknowledgments}

More details on the policy component of the Center for International Forestry Research (CIFOR) Global Comparative Study (GCS) can be found at http://www. forestsclimatechange.org/global-comparative-studyon-redd.html. The methods and guidelines used in this research component were designed by Maria Brockhaus, Monica Di Gregorio and Sheila Wertz-Kanounnikoff.

Parts of the methodology are adapted from the research protocol for media and network analysis designed by Comparing Climate Change Policy Networks (COMPON).

We gratefully acknowledge the support received from the Norwegian Agency for Development Cooperation, the Australian Agency for International Development, the UK Department for International Development, the European Commission, and the US Agency for International Development.

This research was carried out by CIFOR as part of the CGIAR Research Programme, 'Forests, Trees and Agroforestry: Livelihoods, Landscapes and Governance.' The Programme aims to enhance management and use of forests, agroforestry and tree genetic resources across the landscape from forests to farms. The Center for International Forestry Research leads the collaborative Programme in partnership with Bioversity International, the International Center for Tropical Agriculture and the World Agroforestry Centre.

\section{圈} NORWEGIAN MINISTRY OF THE ENVIRONMENT
NORWEGIAN MINISTRY OF FOREIGN AFFAIRS

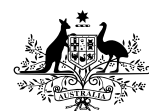

Australian Government AusAID
DFID

Department for International Development
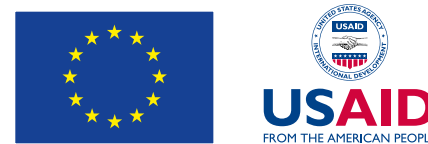